DOI: 10.46340/eppd.2020.7.6.45

\author{
Antonina Bobkova, ScD in Law, academician \\ ORCID ID: https://orcid.org/0000-0002-0834-7514 \\ National Academy of Legal Sciences of Ukraine \\ Volodymyr Panasiuk \\ ORCID ID: https://orcid.org/0000-0002-7826-030X \\ Vasyl' Stus Donetsk National University, Ukraine
}

\title{
TYPES OF RENTAL ENTITIES \\ OF THE MILITARY PROPERTY \\ IN UKRAINE
}

\author{
Антоніна Бобкова, д. ю. н., академік \\ Національна академія правових наук України
}

\author{
Володимир Панасюк \\ Донецький національний університет імені Василя Стуса, Україна
}

\section{ВИДИ СУБ'СКТІВ ОРЕНДИ ВІЙСЬКОВОГО МАЙНА В УКРАЇНІ}

The article analyzes the issues of subjects of military property rent on the basis of scientific literature and general provisions of the legislation on property rent, and also on the relevant provisions of the legislation on property rent of the Armed Forces of Ukraine. It was determined that such issues are regulated by special norms of different levels of legal acts, including the laws of Ukraine "On economic activity in the Armed Forces of Ukraine", "On the Armed Forces of Ukraine" and others. It was found that the issue of the subjects of the military property rent was not fully studied in the theory of economic law.

Taking into consideration the general provisions, the subjects of military property rent were identified and differentiated into certain types. Article 3 of the Law of Ukraine "On economic activity in the Armed Forces of Ukraine" was taken as the point, which includes military units, institutions, authorities and organizations of the Armed Forces of Ukraine, which are maintained for the expenses of the State Budget of Ukraine, run its own domestic economy, have estimates of revenues and expenditures, bank accounts, a seal with the image of the State Emblem of Ukraine and its name.

Each type of military property entities rent was analyzed, their characteristics and certain features were identified and given in this paper. Judicial practice was proposed for each type.

Practice analysis lead to the conclusion that the types of subjects of military property rent need to be clarified at the legislative level with the specification of differences in the legal regime of their property, the scope and conditions of such economic activity, the economic rights and obligations of these entities. It was proposed to make such clarifications in the Law of Ukraine "On Economic Activity in the Armed Forces of Ukraine".

Keywords: subjects, military property, military unit, institutions, authorities and organizations.

Постановка проблеми. Одним із ефективніших видів господарської діяльності у Збройних Силах України є оренда військового майна. Особливості цієї діяльності та правові засади ії здійснення значною мірою визначаються її суб'єктним складом.

На практиці суб'єктами оренди військового майна як виду господарської діяльності виступають військові частини та інші суб'єкти, передбачені законодавством. Водночас суб'єктний склад таких відносин змінюється, з'являються нові суб'єкти, правовий статус яких залишається невизначеним, що стримує ці відносини. 
Суб’єктний склад Збройних Сил України на законодавчому рівні визначають Закони України «Про Збройні Сили України», «Про господарську діяльність у Збройних Силах України», що певною мірою конкретизовані у Порядку реєстрації військових частин як суб'єктів господарської діяльності у Збройних Силах затверджений постановою Кабінету Міністрів України та інші. Разом з тим окремі положення законодавства щодо суб'єктів оренди як виду господарської діяльності у Збройних Силах України потребують конкретизації.

Аналіз останніх досліджень та публікацій.В теорії загальне поняття суб'єкта права досліджували Г. Ф. Шершеневич, С. Н. Трубецькой, І.А. Ільїн, О.С. Рождественська та інші. В господарському праві різним аспектам статусу суб'єктів господарювання приділяли увагу В.С. Щербина, А.Г. Бобкова, С.М. Грудницька, Р.А. Джабраілов, І.В. Труш, О.В. Гарагонич та інші. Військові частини як су'бєкти господарської діяльності досліджували В.Й. Кісель, Е.Г. Бойченко та інші.

Виділення невирішених раніше частин загальної проблеми. Залишаються теоретичні питання щодо видів суб'єктів оренди військового майна, які вимагають уточнення.

Метою дослідження $є$ уточнення видів суб'єктів оренди військового майна як господарської діяльності.

Виклад основного матеріалу. Питання суб'єктів оренди військового майна грунтуються на загальних положеннях щодо суб'єктів права. Зокрема, Г. Ф. Шершеневич ${ }^{1}$ зазначив, що таке поняття вживається двояко. Так, суб'єкт в одному розумінні це носій права, а в іншому це носій обов'язку. В свою чергу С. Н. Трубецькой суб'єктом права називає кожного, хто здатний мати права, незалежно від того, користується він ними насправді чи ні²

Аналогічно вважає I. А. Ільїн, який писав, що суб'єкт права - це той за ким право визнає відомі повноваження, заборони та обов'язки і завдання правових норм у тому, щоб установлювати правові стани суб' єктів. Для того, щоб будь-яке повноваження (або заборона чи обов'язок) належало якомусь суб' єкту права, необхідно, щоб правові норми визнали за ним узагалі здатність мати ці повноваження (або заборону чи обов'язок) . $^{3}$

Зазначені та інші положення склали основу для розуміння суб'єктів господарської діяльності, які отримали розвиток в роботах вчених-господарників (В.С. Щербина ${ }^{4}$, А.Г. Бобкова ${ }^{5}$, С.М. Грудницька ${ }^{6}$, Р.А. Джабраїлов ${ }^{7}$ та інші). В науковій літературі приділялась певна увага і суб'єктам господарської діяльності в Збройних Силах України (В.С. Щербина ${ }^{3}$, Е.Г. Бойченко ${ }^{8}$ ), проте на сьогодні склад і поділ суб’єктів господарювання Збройних Сил України з часів дослідження цими авторами змінився і потребує уточнення.

В законодавстві положення щодо суб'єктів господарювання закріплені ч.1 ст. 55 ГК України, які повно відображають суть суб'єкта господарювання. Так, суб'єктами господарювання визнаються учасники господарських відносин, які здійснюють господарську діяльність, реалізують господарську компетенцію (сукупність господарських прав та обов'язків), мають відокремлене майно і несуть відповідальність за своїми зобов'язаннями в межах цього майна, крім випадків, передбачених законодавством.

Для досягнення мети дослідження доцільно взяти за основу загальні положення щодо суб'єктів господарювання з урахуванням особливостей суб'єктного складу оренди військового майна. Цілком доречним при розгляді суб'єктів оренди військового майна є підхід В.С. Щербини, який зазначив, що класифікація суб'єктів господарського права на види здійснюється згідно з об'єктивним матеріальним критерієм, яким є зміст діяльності або функції суб'єкта, які він виконує в економічній системі України‥ При цьому він виокремлює суб’єктів господарської діяльності у Збройних Силах

\footnotetext{
${ }^{1}$ Шершеневич, Г. Ф. (1995). Общзая теория права. Учебное пособие. Москва: Юридический колледж МГУ, 362.

2 Трубецкой, Е. Н. (1917). Лекции по энцииклопедии права. Москва: т-во типографіи А. И. Мамонтова, 227.

${ }^{3}$ Ильин, И. А. (2006). Общее учение о праве и государстве. Москва: АСТ, Хранитель.

${ }^{4}$ Щербина, В. С. (2008). Суб’єкти господарського права: монографія. Київ, Юрінком Інтер, 264.

${ }^{5}$ Бобкова, А. Г. (2000). Правове забезпечення рекреаційної діяльності. Донецьк, Юго-Восток, 308.

${ }^{6}$ Грудницька, С. М. (2011). Хозяйственная правосубъектность государственных предприятий: проблемы теории и практики. Донецьк, Юго-Восток, 428.

7 Джабраїлов, Р. А. (2010). Господарська правосуб 'єктність міста: теорія і практика. Донецьк: Ноулідж, 455.

${ }^{8}$ Бойченко, Е. Г. (2015). Правове регулювання господарської діяльності військових частин Збройних Сил України: дисертація на здобуття наукового ступеня кандидат юридичних наук. Одеса: НУ «Одеська юридична академія», 241.

${ }^{9}$ Щербина, В. С. (2008). Суб’єкти господарського права. Київ: Юрінком Інтер, 264.
} 
України в особливий вид суб’єктів господарювання, до яких відносяться і суб'єкти оренди військового майна.

На законодавчому рівні визначено загальні засади щодо суб'єктів Збройних Сил України. Відповідно до ч. 3 ст. 3 Закону України «Про Збройні Сили України» Збройні Сили України поділяються на наступні суб'єкти - органи військового управління, 3'єднання, військові частини, військові навчальні заклади, установи та організації .

Суб' єктний склад саме господарської діяльності в Збройних Силах України визначено ст. 3 Закону України «Про господарську діяльність у Збройних Силах України», де до суб'єктів віднесено військові частини, заклади, установи та організації Збройних Сил України, які утримуються за рахунок коштів Державного бюджету України, ведуть відокремлене господарство, мають кошторис надходжень та видатків, рахунки в установах банків, печатку із зображенням Державного Герба України і своїм найменуванням².

Найбільш поширеним суб’єктом Збройних Сил України $є$ військова частина. Так, військова частина А2171 виступала орендодавцем щодо військового майна у відносинах з ТОВ “Фірма ветеран Збройних Сил”, що слідує зі справи №916/146/15-г (постанова Верховного Суду від 8 серпня 2018 р.)․․

Як визначено у законодавстві, військові частини - це військові частини, заклади, установи та організації Збройних Сил України ${ }^{4}$. Визначення поняття як «військова частина - це військова частина» $€$ доволі суперечливим, бо така тафтологія призводить до того, що сам зміст цього поняття не розкрито. Крім того, якщо заклади, установи та організації підпадають під поняття військової частини, то виникає цілком логічне питання щодо доцільності використання у нормативно-правових актах окремо понять «заклади, установи та організації».

Більш конкретним $\epsilon$ визначення військової частини як типової організаційної одиниці, що утримається на окремому штаті і призначається для виконання визначених завдань самостійно або у складі організаційної структури вищого рівня. Під військовими частинами розуміють органи військового управління, з'єднання, військові частини, військові кораблі (екіпажі), військові навчальні заклади та установи 5 . Водночас і таке визначення потребує уточнення щодо розуміння військових частин як суб'єктів оренди військового майна.

В науковій літературі визначення військової частини конкретизував В. Й. Кісель, який запропонував поняття військової частини як створеного з метою забезпечення обороноздатності та безпеки держави основного військового підрозділу Збройних Сил України, сформованого переважно 3 числа військовослужбовців, оснащеного зброєю, бойовою технікою, іншим майном, який має своє дійсне та умовне найменування, фінансується з коштів Державного бюджету, веде самостійне господарство, має кошторис надходжень та видатків, рахунки в установах банків, печатки із зображенням Державного Герба України i своїм найменуванням. Крім того науковцем запропоновано визначення військової частини як юридичної особи, а саме - це організація, яка має у оперативному управлінні майно, може від свого імені набувати і здійснювати майнові та особисті немайнові права і нести відповідні обов'язки, здатна самостійно відповідати за своїми зобов'язаннями та бути позивачем і відповідачем у суді'.

Такі пропозиції представляють інтерес для визначення військової частини як окремих суб'єктів оренди. Водночас таке визначення можна уточнити, що військова частина як суб'єкт оренди військового майна - це самостійна основна військова організація Збройних Сил України, що створена у встановленому законом порядку для здійснення спеціальних функцій, яка має відокремлене майно, наділена відповідними господарськими правами та обов'язками, здатна самостійно відповідати за своїми зобов'язаннями та бути позивачем і відповідачем у суді і управнена здійснювати оренду військового майна у порядку та на умовах, визначених законом.

\footnotetext{
1 Закон про Збройні Сили Украйни, 2000 (Верховна Рада України). Відомості Верховної Ради України, 48, 410.

2 Закон про господарську діяльність у Збройних Силах України, 1999 (Верховна Рада України). Відомості

Верховної Ради України, 48, 408.

${ }^{3}$ Постанова у справі №916/146/15-г, 2018 (Верховний Суд України). Реєстр судових рішень України

<http://reyestr.court.gov.ua/Review/>. (2020, листопад, 12).

${ }^{4}$ Наказ про затвердження Порядку обліку платників податків, зборів (обов'язкових платежів)

затверджений, 1998 (Державна податкова адміністрація). Офіџійний вісник Украӥни, 11, 118, 431.

${ }^{5}$ Наказ Про затвердження Зводу відомостей, що становлять державну таємнищю 2005 (Служба безпеки України).

Офіиійний вісник України, 34, 2089.

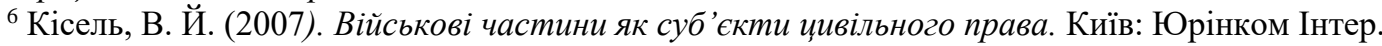


Таким чином, в нормативно-правових актах поняття військової частини потребує визначення як окремого суб'єкта Збройних Сил України та суб'єкта господарської діяльності в Збройних Силах України, що буде стосуватись і оренди військового майна. Водночас, незважаючи на найбільшу кількість військових частин серед суб'єктів Збройних Сил України, в орендні відносини вони вступають не так часто.

Наступним суб’ єктом оренди військового майна у Законі України «Про господарську діяльність у Збройних Силах України» названо заклади, які представлені військовими навчальними закладами.

Так, освітню діяльність провадять 2 університети, 4 академії, 6 військових інститути, 3 військові коледжі сержантського складу, 1 відділення військової підготовки, 33 кафедри військової підготовки, 10 кафедр медицини катастроф та військової медицини, 3 військові ліцеї. Серед таких закладів, наприклад, «Військовий інститут телекомунікації та інформатизації Національного технічного університету України “Київський політехнічний інститут", Академія Сухопутних військ імені гетьмана Петра Сагайдачного, Харківський університет Повітряних Сил імені Івана Кожедуба, Військова академія, Академія Військово-Морських Сил імені П.С. Нахімова, Військовий інститут Київського національного університету імені Тараса Шевченка та інші ${ }^{1}$.

За загальним визначенням заклад освіти це юридична особа публічного чи приватного права, основним видом діяльності якої $є$ освітня діяльність ${ }^{2}$. Військові навчальні заклади забезпечують відповідно до ст. 21 Закону України «Про освіту» спеціалізовану освіту. яка може здобуватися в рамках формальної, неформальної, інформальної освіти, спрямована на здобуття компетентностей у відповідній сфері професійної діяльності під час навчання у безперервному інтегрованому освітньому процесі на кількох або всіх рівнях освіти та потребує раннього виявлення і розвитку індивідуальних здібностей.

Визначення військового навчального закладу законодавство не містить натомість існує визначення вищого військовго навчального закладу, яке надано у Положенні про вищі військові навчальні заклади затвердженому наказом Міністерства оборони України від 27.05.2015 p. №240. В ньому зазначено, що вищі військові навчальні заклади - це вищий навчальний заклад державної форми власності, який здійснює на певних рівнях вищої освіти підготовку, перепідготовку та підвищення кваліфікації військових фахівців для подальшої служби на посадах офіцерського (сержантського, старшинського) або начальницького складу з метою задоволення потреб Збройних Сил України, інших утворених відповідно до законів України військових формувань, проводить наукову, науково-технічну, інноваційну та/або методичну діяльність ${ }^{3}$.

Участь військових навчальних закладів в орендних відносинах має низку особливостей. Вони обумовлені як віднесенням цих суб'єктів до спеціальних навчальних закладів, так і загальними умовами участі закладів освіти в таких відносинах. Право на передачу в оренду майна передбачено ст. 80 Закону України «Про освіту» та обмежено тим, що майно закладів освіти не підлягає використанню не за освітнім призначенням ${ }^{4}$. Наразі дозволено надання в оренду майна, яке перебуває на балансі закладів освіти з метою надання послуг, які не можуть бути забезпечені безпосередньо закладами освіти, пов'язаних із забезпеченням освітнього процесу або обслуговуванням учасників освітнього процесу, з урахуванням визначення органом управління можливості користування державним нерухомим майном відповідно до законодавства».

Таке положення названого Закону викликало запитання щодо потреб, які відносяться до тих, що не можуть забезпечуватися самим закладом освіти, адже від його вирішення залежатиме для яких цілей можна здавати в оренду майно навчального закладу. Певним чином відповідь на це питання міститься у постанові Кабінету Міністрів України від 27.08.2010 р. №796 «Про затвердження переліку платних послуг, які можуть надаватися закладами освіти, іншими установами та закладами системи освіти, що належать до державної і комунальної форми власності» ${ }^{5}$. Цією постановою серед послуг,

\footnotetext{
${ }^{1}$ Офіційний сайт Міністерства оборони України (2020). Головна сторінка

<https://www.mil.gov.ua/diyalnist/vijskova-osvita-na-tauka/> (2020, листопад, 30).

2 Закон про освіту, 2017 (Верховна Рада України). Голос України, 178, 179.

${ }^{3}$ Наказ про затвердження Положення про вищі військові навчальні заклади, 2015 (Міністерство оборони України). Офіиійний вісник Украӥни, 55, 858, 1819.

4 Закон про освіту, 2017 (Верховна Рада України). Голос України , 178, 179.

${ }^{5}$ Постанова про затвердження переліку платних послуг, які можуть надаватися закладами освіти, іншими установами та закладами системи освіти, щзо належать до державної і комунальної форми власності, 2010 (Кабінет Міністрів України). Офіційний вісник Украӥни, 67, 71, 2410.
} 
які можуть надаватися закладами освіти, іншими установами та закладами системи освіти, що належать до державної і комунальної форми власності, передбачено передача в оренду відповідного нерухомого майна тим, хто ці послуги зможе надати. При цьому передбачено, що майно навчального закладу яке передається в оренду, повинно тимчасово не використовуватись у освітній, навчальновиховній, навчально-виробничій, науковій діяльності і не погіршувати соціально-побутових умов осіб, які навчаються або працюють у закладі освіти.

Водночас на практиці неодинокі випадки, коли допускаються помилки щодо віднесення послуг до дозволених як умови передання приміщень закладів освіти в оренду. Так, визнано неправомірним розміщення на території закладу освіти відділення банку, бо це не відноситься і не має нічого спільного з навчальним процесом (постанова Вищого господарського суду України по справі №904/1530/16 від 25.10.2017 р. $)^{1}$. Не визнано використанням приміщення за освітнім призначенням i у випадку здачі в оренду приміщень закладу освіти з метою реалізації продовольчих та непродовольчих товарів, (постанова Вищий господарський суд України по справі №907/323/15 від 24.11.2015 р. $)^{2}$. Наразі такі підходи обмежують права закладів освіти на передання в оренду майна, оскільки перелік дозволених товарів чи послуг відсутній, а будь-які з них можуть використовувати учасники освітнього процесу.

Наведене стосується і воєнних закладів освіти, здача в оренду якими має ще і спеціальні обмеження, що слідують із належності закріпленого за ними майна до категорії воєнного та наявності окремого правового режиму такого майна. На практиці подекуди встановлено і додаткові обмеження оренди майна військових закладів освіти. Так, п. 1.11 Положення про Військовий інститут Київського національного університету імені Тараса Шевченка затвердженого наказом Міністерства освіти i науки України, Міністерства оборони України від 18.04.2014 №483/260 встановлено, що питання про надання в оренду будівель, споруд, приміщень, навчального й наукового обладнання та іншого майна Військового інституту для забезпечення діяльності будь-яких сторонніх державних, громадських чи комерційних організацій вирішується ректором Університету ${ }^{3}$.

Для забезпечення можливості здійснювати військовими навчальними закладами такої господарської діяльності як оренда військового майна доцільно з урахуванням подвійних обмежень розробити та затвердити рекомендації щодо таких відносин, які сприятимуть більш ефективному використанню такого майна та мінімізації відповідних порушень.

Ще одним суб'єктом оренди військового майна, на якого вказує Закон України «Про господарську діяльність в Збройних Силах України» є установи. За загальноприйнятим визначенням установа - це організація, створена однією або кількома особами (засновниками), які не беруть участі в управлінні нею, шляхом об'єднання (виділення) їхнього майна для досягнення мети, визначеної засновниками, за рахунок цього майна (ст.83 ЦК України) ${ }^{4}$. Прикладом участі установи Збройних Сил України в орендних відносинах є здача в оренду навчально-спортивною базою літніх видів спорту Міністерства оборони України освітлювальної вежі стадіону цієї бази. (постанова Вищого господарського суду України від 01.04.2010 р. по справі №31/231)

Найбільш поширеним прикладом установи у Збройних Силах України, що мають право на здійснення оренди військового майна, є квартирно-експлуатаційні органи Збройних Сил, до яких відносяться: Головне квартирно-експлуатаційне управління Збройних Сил України, територіальні квартирно-експлуатаційні управління та Київське квартирно-експлуатаційне управління, квартирноексплуатаційні відділи (квартирно-експлуатаційні частини) України ${ }^{6}$.

Як правило, орендою нерухомого військового майна та земельних ділянок займаються квартирно-експлуатаційні управління та відділи. Так, наприклад Головне квартирно-експлуатаційне управління МОУ було орендодавцем нерухомого майна, яке являло собою нежитлові приміщення

\footnotetext{
${ }^{1}$ Постанова у справі №904/1530/16, 2017 (Вищий господарський суд України). Реєстр судових рішень України <http://reyestr.court.gov.ua/Review/> (2020, листопад, 30).

${ }^{2}$ Постанова у справі №907/323/15, 2015 (Вищий господарський суд України). Реєстр судових рімень Украӥни <http://reyestr.court.gov.ua/Review/> (2020. листопада, 30).

${ }^{3}$ Наказ про затвердження положення про Військовий інститут Київського національного університету імені Тараса Шевченка, 2014 (Міністерство освіти і науки України).

<https://zakon.rada.gov.ua/rada/show/v0483729-14\#Text> (2020. листопада, 30).

${ }^{4}$ Цивільний кодекс Украӥни, 2003.(Верховна Рада України). Голос України , 45.

${ }^{5}$ Постанова у справі №31/231, 2010 (Вищий господарський суд України) <http://reyestr.court.gov.ua/Review/> (2020, листопада, 30).

${ }^{6}$ Наказ про затвердження Положення про організацію квартирно-експлуатаційного забезпечення Збройних Сил Украӥни (Міністерство оборони України). Офічійний вісник Украӥни 75, 133, 2784.
} 
загальною площею 455,7 кв.м. розташованого у м. Одеса (постанова Великої Палати Верховного Суду від 03.07.2018 р. по справі №916/559/17) ${ }^{1}$. Ще одним прикладом оренди за участі установи $є$ договір оренди, укладений між Квартирно-експлуатаційним відділом м. Чернівці та ТОВ «Ріфіл-Україна» (справа №926/225/17, постанова Верховного Суду від 15.07.2019 року)².

Особливістю участі названих суб'єктів $€$ те, що вони передають в оренду військове майно (військове містечко, квартирне майно тощо), яке використовується іншими суб'єктами, а тому здійснення ними такої господарської діяльності потребує додаткового дослідження та урегулювання.

До суб'єктів оренди військового майна за Законом України «Про господарську діяльність в Збройних Силах України» віднесено і організації Збройних Сил України. Визначення організації як суб' єкта господарських відносин на законодавчому рівні представлено лише в Законі України «Про технічні регламенти та процедури оцінки відповідності» від 01.12.2005 р., за яким «організаціїпідприємства, установи, організації, органи влади чи інші установи, їх підрозділи чи їх об'єднання 3 правами юридичної особи чи без них, громадські організації чи приватні або засновані на іншій формі власності підприємства, установи, організації, які виконують самостійні функції та мають установчий документ (статут) і свою структуру управління» ${ }^{3}$. Аналіз цього визначення вказує на надто широке розуміння такого суб'єкта та використання поняття «організації» як узагальнюючої назви певного кола суб'єктів при застосуванні названого Закону, що є мало прийнятним для використання такого поняття в інших відносинах.

Невизначеність з організаційно-правовою формою організації та ії ознаками рівною мірою стосується і суб'єктів оренди військового майна, а тому включення до кола суб'єктів цих відносин саме організацій втратило сенс.

Ще одним видом суб'єктів оренди військового майна є державні підприємства, особливістю яких $\epsilon$ те, що майно ім належить на праві оперативного управління. За загальноприйнятим визначенням підприємство - це самостійний суб'єкт господарювання, створений компетентним органом державної влади або органом місцевого самоврядування, або іншими суб'єктами для задоволення суспільних та особистих потреб шляхом систематичного здійснення виробничої, науково-дослідної, торговельної, іншої господарської діяльності в порядку, передбаченому Господарським кодексом України та іншими законами ${ }^{4}$. Серед таких суб' єктів, наприклад, державне підприємство Міністерства оборони України «Запорізький автомобільний ремонтний завод», який одночасно має умовне найменування - військова частина $\mathrm{A} 0652^{5}$; державне підприємство Міністерства оборони України «Одеський проектний інститут» ${ }^{6}$, державне підприємство Міністерства оборони України «Львівський проектний інститут» ${ }^{7}$, державне підприємство Міністерства оборони України "Центральний військовий санаторій "Ялтинський", які також виступали орендодавцями військового майна ${ }^{8}$ та ін.

Як свідчить практика, державні підприємства Міністерства оборони України також вступають увідносини оренди військового майна проте у Законі України «Про господарську діяльність у Збройних Силах України» вони відсутні. Це зумовлено тим, що 96 державних підприємств підпорядковано Головному управлінню майна та ресурсів, яке $є$ структурним підрозділом Міністерства оборони України та не входить до складу Збройних Сил України. При цьому частина державних підприємств за усталеними у науці господарського права ознаками є установами, можливості яких займатись орендою майна є значно обмеженими відносно підприємств. Правовий статус створених в різні роки державних підприємств, які наразі мають право здійснювати такий вид

\footnotetext{
${ }^{1}$ Постанова від 03.07.2018 p., у справі №916/559/17 (Велика палата Верховного Суду) Реєстр судових рімень України <http://reyestr.court.gov.ua/Review/> (2020, листопад, 30).

${ }^{2}$ Постанова від 15.07.2019 p., у справі №926/225/17 (Верховний Суд України). Реєстр судових рішень України $<$ http://reyestr.court.gov.ua/Review/83087004> (2020, листопад, 30).

3 Закон про технічні регламенти та процедури оцінки відповідності, 2015 (Верховна Рада України). Голос України, 23.

${ }^{4}$ Господарський кодекс Украӥни, 2003 (Верховна Рада України). Голос Украӥни, 49.

${ }^{5}$ Постанова у справі №908/1064/17, 2018 (Верховний Суд України). Реєстр судових рішень України

<http://reyestr.court.gov.ua/Review/> (2020, листопада, 30).

${ }^{6}$ Рішення у справі №916/3537/15, 2015 (Господарський суд Одеської області). Реєстр судових рішень України <http://reyestr.court.gov.ua/Review/> (2020, листопада, 30).

${ }^{7}$ Постанова у справі №1/606-6/171, 2007 (Львівський апеляційний господарський суд). Реєстр судових рішень України <http://reyestr.court.gov.ua/Review/>(2020, листопада, 30).

${ }^{8}$ Постанова у справі №2-25/6695-2006, 2006 (Вищий господарський суд України). Реєстр судових рішень

України <http://reyestr.court.gov.ua/Review/>(2020, листопада, 30).
} 
господарської діяльності як оренда військового майна, потребує приведення у відповідність до діючого законодавства щодо організаційно-правової форми, правового режиму майна, завдань i напрямів діяльності, відповідальності.

Висновки. Проведене дослідження дозволяє дійти висновку, що суб'єкти оренди військового майна як господарської діяльності поділяються на такі види: військові частини, військові навчальні заклади, установи, державні підприємства. При цьому можна уточнити, що військова частина як суб'єкт оренди військового майна - це самостійна основна військова організація Збройних Сил України, що створена у встановленому законом порядку для здійснення спеціальних функцій, яка має відокремлене майно, наділена відповідними господарськими правами та обов'язками, здатна самостійно відповідати за своїми зобов'язаннями та бути позивачем і відповідачем у суді і управнена здійснювати оренду військового майна у порядку та на умовах, визначених законом.

Види суб'єктів оренди військового майна потребують уточнення на законодавчому рівні 3 конкретизацією відмінностей щодо правового режиму їх майна, обсягу та умов здійснення такої господарської діяльності, господарських прав і обов'язків цих суб'єктів. Такі уточнення доцільно зробити у Законі України «Про господарську діяльність у Збройних Силах України».

\section{References:}

1. Shershenevych, H. F. (1995). Zahalna teoriia prava. Navchalnyi posibnyk. [General theory of law. Tutorial]. Yurydycheskyi kolledzh MHU [College of Law, Moscow State University], 362. [in Ukrainian].

2. Trubetskoi, E. N. (1917). Lektsii po entsyklopedii prava [Lectures on the encyclopedia of law], 227 [in Ukrainian].

3. Ilin, I. A. (2006). Zahalne vchennia pro pravo i derzhavu. [General doctrine of law and the state]. AST, Khranytel [AST, Guardian], 510 [in Ukrainian].

4. Shcherbyna, V. S. (2008). Subiekty hospodarskoho prava: monohrafiia [Subjects of economic law: a monograph]. Kyiv, Yurinkom Inter. [in Ukrainian].

5. Bobkova, A. H. (2000). Pravove zabezpechennia rekreatsiinoi diialnosti [Legal support of recreational activities]. Donetsk, Yuho-Vostok. [in Ukrainian].

6. Hrudnytska, S. M. (2011). Khoziaistvennaia pravosubjektnost hosudarstvennykh predpryiatyi: problemy teoryy y praktyky [Economic legal personality of state enterprises: problems of theory and practice]. Donetsk: Yuho-Vostok. [in Ukrainian].

7. Dzhabrailov, R. A. (2010). Hospodarska pravosubiektnist mista: teoriia i praktyka [Economic legal personality of the city: theory and practice]. Donetsk: Noulidzh. [in Ukrainian].

8. Boichenko, E. H. (2015). Pravove rehuliuvannia hospodarskoi diialnosti viiskovykh chastyn Zbroinykh Syl Ukrainy [Legal regulation of economic activity of military units of the Armed Forces of Ukraine]. Odesa: NU OLA [in Ukrainian].

9. Shcherbyna, V. S. (2008). Subiekty hospodarskoho prava [Business entities]. Kyiv, Yurinkom Inter. [in Ukrainian].

10. Zakon Ukrainy Pro Zbroini Syly Ukrainy, 1991 (Verkhovna Rada Ukrainy) [Law of Ukraine On the Armed Forces of Ukraine, 1991 (Verkhovna Rada Ukrainy)]. Vidomosti Verkhovnoi Rady Ukrainy [Information of the Verkhovna Rada of Ukraine], 9, 108. [in Ukrainian].

11. Zakon Ukrainy Pro hospodarsku diialnist u Zbroinykh Sylakh Ukrainy, 1999 (Verkhovna Rada Ukrainy) [Law of Ukraine On Economic Activity in the Armed Forces of Ukraine 1999 (Verkhovna Rada of Ukraine)]. Oficijnyj visnik Ukrajiny [Official Bulletin of Ukraine], 42, 16 [in Ukrainian].

12. Postanova u spravi №916/146/15-h, 2018 (Verkhovnyy Sud Ukrayiny) [Resolution in case №916 / 146/15-h, 2018 (The Supreme Court of Ukraine)]. Reyestr sudovykh rishen Ukrayiny [Register of court decisions of Ukraine] $<\mathrm{http}: / /$ reyestr.court.gov.ua/Review/> (2020, November, 30). [in Ukrainian].

13. Nakaz pro zatverdzhennia Poriadku obliku platnykiv podatkiv, zboriv (oboviazkovykh platezhiv) zatverdzhenyi, 1998 (Derzhavna podatkova administratsiia) [Order on approval of the Procedure for accounting of taxpayers, fees (mandatory payments), 1998 (State Tax Administration)]. Ofitsiinyi visnyk Ukrainy [Officials visnik of Ukraine], $11,118,431$ [in Ukrainian].

14. Nakaz Pro zatverdzhennia Zvodu vidomostei, shcho stanovliat derzhavnu taiemnytsiu, 2005 (Sluzhba bezpeky Ukrainy) [Order On Approval of the Code of Information Constituting a State Secret, 2005 (Security Service of Ukraine)]. Ofitsiinyi visnyk Ukrainy [Official Gazette of Ukraine], 34, 2089. [in Ukrainian].

15. Kisel, V. Y. (2007). Viiskovi chastyny yak subiekty tsyvilnoho prava [Military units as subjects of civil law]. Kyiv, Yurinkom Inter, [in Ukrainian].

16. Ofitsinyi sait Ministerstva oborony Ukrainy [Official site of the Ministry of Defense of Ukraine] (2020). Holovna storinka [Homepage] <https://www.mil.gov.ua/diyalnist/vijskova-osvita-na-tauka/>(2020, November, 30).

17. Nakaz pro zatverdzhennia Polozhennia pro vyshchi viiskovi navchalni zaklady, 2015 (Ministerstvo oborony Ukrainy) [Order approving the Regulations on Higher Military Educational Institutions, 2015 (Ministry of Defense of Ukraine)]. Ofitsiinyi visnyk Ukrainy [Official Gazette of Ukraine], 55, 858, 1819 [in Ukrainian].

18. Zakon pro osvitu, 2017 (Verkhovna Rada Ukrainy) [Law on Education, 2017 (Verkhovna Rada of Ukraine)]. Holos Ukrainy [Voice of Ukraine], 178, 179 [in Ukrainian]. 
19. Postanova pro zatverdzhennia pereliku platnykh posluh, yaki mozhut nadavatysia zakladamy osvity, inshymy ustanovamy ta zakladamy systemy osvity, shcho nalezhat do derzhavnoi i komunalnoi formy vlasnosti, 2019 (Kabinet Ministriv Ukrainy) [Resolution on approval of the list of paid services that may be provided by educational institutions, other institutions and institutions of the educational system belonging to the state and communal form of ownership, 2019 (Cabinet of Ministers of Ukraine)]. Ofitsiinyi visnyk Ukrainy [Official Gazette of Ukraine], 67, 71, 2410 [in Ukrainian].

20. Postanova u spravi №904/1530/16, 2017 (Vyshchyi hospodarskyi sud Ukrainy) [Resolution in case №904 / 1530/16, 2017 (Supreme Commercial Court of Ukraine)]. Reyestr sudovykh rishen Ukrayiny [Register of court decisions of Ukraine] <http://reyestr.court.gov.ua/Review/> (2020, November, 30). [in Ukrainian].

21. Postanova vid 24.11.2015 r., u spravi №907/323/15 (Vyshchyi hospodarskyi sud Ukrainy) [Resolution of 24.11.2015, in case №907 / 323/15 (Supreme Commercial Court of Ukraine)]. Reyestr sudovykh rishen Ukrayiny [Register of court decisions of Ukraine] <http://reyestr.court.gov.ua/Review/> (2020, November, 30). [in Ukrainian].

22. Nakaz pro zatverdzhennia polozhennia pro Viiskovyi instytut Kyivskoho natsionalnoho universytetu imeni Tarasa Shevchenka 2014 (Ministerstvo osvity i nauky Ukrainy) [Order approving the regulations on the Military Institute of the Taras Shevchenko National University of Kyiv, 2014. (Ministry of Education and Science of Ukraine)] <https://zakon.rada.gov.ua/rada/show/v0483729-14\#Text> (2020, November 30). [in Ukrainian].

23. Tsyvilnyi kodeks Ukrainy, 2003 (Verkhovna Rada Ukrainy) [Civil Code of Ukraine, 2003 (Verkhovna Rada of Ukraine)]. Holos Ukrainy [Voice of Ukraine], 45[in Ukrainian].

24. Postanova vid 01.04.2010 r., u spravi №31/231 (Vyshchyi hospodarskyi sud Ukrainy) [Resolution of 01.04.2010, in case №31 / 231 (Supreme Commercial Court of Ukraine)]. Reyestr sudovykh rishen Ukrayiny [Register of court decisions of Ukraine] <http://reyestr.court.gov.ua/Review/> (2020, November, 30). [in Ukrainian].

25. Nakaz pro zatverdzhennia Polozhennia pro orhanizatsiiu kvartyrno-ekspluatatsiinoho zabezpechennia Zbroinykh Syl Ukrainy, 2007 (Ministerstvo oborony Ukrainy) [Order approving the Regulations on the organization of housing and operational support of the Armed Forces of Ukraine (Ministry of Defense of Ukraine), 2007]. Ofitsiinyi visnyk Ukrainy [Official Gazette of Ukraine] 75, 133, 2784 [in Ukrainian].

26. Postanova u spravi №916/559/17, 2018 (Velyka palata Verkhovnoho Sudu) [Resolution in case №916 / 559/17, 2018 (Grand Chamber of the Supreme Court)]. Reyestr sudovykh rishen Ukrayiny [Register of court decisions of Ukraine] <http://reyestr.court.gov.ua/Review/> (2020, November, 30). [in Ukrainian].

27. Postanova u spravi №926/225/17, 2019 (Verkhovnyi Sud) [Resolution in case №926/225/17, 2019 (Supreme Court)] Reyestr sudovykh rishen Ukrayiny [Register of court decisions of Ukraine] <http://reyestr.court.gov.ua/Review/83087004> (2020, November, 30). [in Ukrainian].

28. Zakon pro tekhnichni rehlamenty ta protsedury otsinky vidpovidnosti, 2015 (Verkhovna Rada Ukrainy) [Law on Technical Regulations and Conformity Assessment Procedures, 2015 (Verkhovna Rada of Ukraine)]. Holos Ukrainy [Voice of Ukraine], 23 [in Ukrainian].

29. Hospodarskyi kodeks Ukrainy, 2003 (Verkhovna Rada Ukrainy) [Commercial Code of Ukraine, 2003 (Verkhovna Rada of Ukraine)]. Holos Ukrainy [Voice of Ukraine], 49 [in Ukrainian].

30. Postanova u spravi №908/1064/17, 2018 (Verkhovnyi Sud) [Resolution in case №908/1064/17, 2018 (Supreme Court)] Reyestr sudovykh rishen Ukrayiny [Register of court decisions of Ukraine] <http://reyestr.court.gov.ua/Review/> (2020, November, 30). [in Ukrainian].

31. Rishennia u spravi №916/3537/15, 2015 (Hospodarskyi sud Odeskoi oblasti) [Decision in the case №916/3537/15, 2015 (Commercial Court of Odessa region)]. Reyestr sudovykh rishen Ukrayiny [Register of court decisions of Ukraine] <http://reyestr.court.gov.ua/Review/> (2020, November, 30). [in Ukrainian].

32. Postanova u spravi №1/606-6/171, 2007 (Lvivskyi apeliatsiinyi hospodarskyi sud) [Resolution in case №1/606-6/171, 2007 (Lviv Commercial Court of Appeal)] Reyestr sudovykh rishen Ukrayiny [Register of court decisions of Ukraine] <http://reyestr.court.gov.ua/Review/> (2020, November, 30). [in Ukrainian].

33. Postanova u spravi №2-25/6695-2006, 2006 (Vyshchyi hospodarskyi sud Ukrainy) [Resolution in case №2-25/6695-2006, 2006 <Supreme Commercial Court of Ukraine]. Reyestr sudovykh rishen Ukrayiny [Register of court decisions of Ukraine] <http://reyestr.court.gov.ua/Review/> (2020, November, 30). [in Ukrainian].

34. Postanova u spravi №908/1064/17, 2018 (Verkhovnyi Sud Ukrainy) [Resolution in case №908/1064/17, 2018 (Supreme Court OF Ukraine)] <http://reyestr.court.gov.ua/Review/> (2020, November, 30). [in Ukrainian].

35. Rishennia u spravi №916/3537/15, 2015 (Hospodarskyi sud Odeskoi oblasti) [Decision in the case №916/3537/15, 2015 (Commercial Court of Odessa region)]. Reyestr sudovykh rishen Ukrayiny [Register of court decisions of Ukraine] <http://reyestr.court.gov.ua/Review/> (2020, November, 30). [in Ukrainian].

36. Postanova u spravi №1/606-6/171, 2007 (Lvivskyi apeliatsiinyi hospodarskyi sud) [Resolution in case №1/606-6/171, 2007 (Lviv Commercial Court of Appeal)]. Reyestr sudovykh rishen Ukrayiny [Register of court decisions of Ukraine] <http://reyestr.court.gov.ua/Review/> (2020, November, 30). [in Ukrainian].

37. Postanova u spravi №2-25/6695-2006, 2006 (Vyshchyi hospodarskyi sud Ukrainy) [Resolution in case №2-25/6695-2006, 2006 <Supreme Commercial Court of Ukraine]. Reyestr sudovykh rishen Ukrayiny [Register of court decisions of Ukraine] <http://reyestr.court.gov.ua/Review/>(2020, November, 30). [in Ukrainian]. 